\title{
Chapter 4 \\ Composting in Sri Lanka: Policies, \\ Practices, Challenges, and Emerging \\ Concerns
}

\author{
Warshi S. Dandeniya and Serena Caucci
}

\begin{abstract}
Compost is a widely accepted organic fertiliser throughout the world. It is being produced using a wide variety of source materials at household to commercial scale. With the increased population and changes in food consumption pattern tending towards a vegetable- and meat-rich diet, the amount of organic waste generated in urban and peri-urban settings has increased. Many governments promote composting as a process that helps them to reduce the volume of organic waste and recycle nutrients back to croplands. Some examples of organic waste accumulated in large scale include household waste from urban and peri-urban settings, sewage, animal farm waste, agricultural waste from large-scale markets, food debris, and kitchen waste from hotels. The composition of compost varies in a wide range depending on the nature of materials used to produce it. The safety concerns related to compost also vary along the same line. The quality of compost has become a subjective term that means different aspects to different bodies due to a lack of commonly agreed standards to regulate the composting process and the final product itself. Recent research findings indicate that compost can serve as a carrier of potentially toxic trace elements, organic pollutants, and determinants of antimicrobial resistance to the environment and along the food chain. Producing good-quality compost safe to human health and the environment at large has become a challenge that should be addressed at various levels: from production to policymaking. This chapter discusses some of the major challenges faced in Sri Lanka with compost making. To prepare the background for this discussion, information on the policies and current practices of nutrient management in Sri Lanka is also presented. The context may be applicable to many other developing countries in the tropics.
\end{abstract}

\footnotetext{
W. S. Dandeniya $(\bowtie)$

Department of Soil Science, Faculty of Agriculture, University of Peradeniya, Peradeniya, Sri Lanka

e-mail: warshisd@pdn.ac.lk

S. Caucci

United Nations University (UNU-FLORES), Dresden, Sachsen, Germany

e-mail: caucci@unu.edu 
Keywords Animal manure - Antibiotic resistance $\cdot$ Compost $\cdot$ Fertiliser · Municipal solid waste $\cdot$ Organic pollutants

\section{Introduction}

Compost can be used as a nutrient source in crop cultivation and often increase productivity when used in combination with chemical fertilisers. It is a popular fertiliser in organic farming and in integrated nutrient management systems. However, the long-term use of compost in large quantities and/or application of poor-quality compost to soil can deteriorate environmental quality and pose a threat to the safety of food (Deportes et al. 1995; Garcia-Gil et al. 2000; Smith 2009, 2018). The progressive accumulation of toxic trace elements such as $\mathrm{Pb}$ and $\mathrm{Cd}$ in soils has been reported in several studies where long-term application of compost produced from municipal solid waste (MSW) was applied (Garcia-Gil et al. 2000; Smith 2009). The contamination of food items with potentially toxic trace elements and human pathogens due to the application of compost to crops has been reported in literature (Deportes et al. 1995; Johannessen et al. 2004; Smith 2009; Maffei et al. 2013).

Several types of composts are being produced and these differ in terms of starting material combinations and methods to cater to unique requirements. For example, easily biodegradable and nutrient-rich wastes like animal manures are used to produce compost, when compost is required as a source of nutrients to substitute chemical fertilisers (Garcia-Gil et al. 2000). Biochar like more recalcitrant carbon has been added to compost lately, when applied to cultivate soil fertility in the long term (Agegnehu et al. 2015). Municipal solid waste composting is commonly known as a method for reducing and recycling waste, and the product is being used in landfills and for environmental restoration purposes (Hurst et al. 2005). Therefore, the quality and safety concerns of compost heavily depend on the nature of materials used to produce compost as well as on the intended goals of end use (Garcia-Gil et al. 2000; Hurst et al. 2005; Smith 2009; Agegnehu et al. 2015). The use of compost such as those made using MSW, with a risk of containing potentially toxic contaminants, is often encouraged to be limited to contained environments or in systems that have no direct link to the human food chain. However, there is no consistency in how people use those products as some use such compost in landfills, while some apply it in crop fields. In many countries, there is only one set of standards regarding the composition of compost and common guidelines to follow during marketing irrespective of the diversity in the nature of materials used, method of composting, and intended end use. Further, the standards are limited to well-known parameters like moisture and sand contents; contents of nutrients as N, P, and K; and a few potentially toxic trace elements and carbon content. There are no standards for organic contaminants including volatile compounds and antibiotics.

Compost is comprised of a mixture of complex forms of nutrients and microorganisms, and once applied to soil, it replenishes the soil nutrient pool while 
improving several soil fertility aspects. Therefore, compost application is highly recommended to soils with declined fertility status to improve productivity levels. Soils occupying the agricultural lands in Sri Lanka are inherently low in organic matter content and overall soil fertility. Compost as an organic fertiliser could be used to improve both the organic carbon pool and crop productivity in these soils in Sri Lanka. Understanding the gaps in knowledge on the safety and quality aspects of the composting process and final product itself is very important to promote responsible production and use of the material. In this context, this chapter discusses the policy aspects, the current practices with an emphasis on quality and safety concerns, and the challenges of compost making in Sri Lanka.

\section{Agricultural Nutrient Management Practices in Sri Lanka}

Historical evidences indicate that traditionally Sri Lankan farmers used organic inputs such as animal manures, crop residues, and green manures and biodynamic farming techniques, crop rotations, shifting cultivation, and crop diversification as measures for managing soil fertility. Colonisation by the Portuguese and Dutch followed by the British from the mid-sixteenth to mid-nineteenth century gradually changed the land-use pattern in the country, mainly transforming traditional subsistence farming systems to export-based commercial plantation agriculture (Mapa 2003). Organic and biodynamic means of farming continued for locally consumed food crop production until the introduction of high-yielding crop varieties and synthetic fertilisers for nutrient management with the 'green revolution' in the 1960s, aiming to improve crop yields to meet the growing demand for food (Nagarajah 1986; Palm and Sandell 1989). Some farmers used an integrated approach in nutrient management by combining biodynamic methods and organic farming techniques with synthetic fertiliser application. Later research entities and the Department of Agriculture identified the importance of finding integrated soil fertility management approaches for nutrient management due to growing concerns about nutrient depletion and overall fertility decline in agricultural soils managed with synthetic fertiliser inputs. With advancements in knowledge on soil nutrient dynamics and the interactive role of soil physical, chemical, and biological properties on plant performances, a paradigm shift in nutrient management took place across the globe in the 1980s from external input management to integrated soil fertility management (Sanchez 1997). As a result, the composting techniques, compost application rates, and benefits of applying compost were researched extensively in many parts of the world, including in Sri Lanka. In the late 1990s, compost application rates were incorporated to fertiliser recommendations of some food crops in Sri Lanka. However, organic fertiliser application was not popular among farmers due to a lack of availability of materials, poor motivation to produce compost on-farm, and issues with timing of compost production with material and resource availability for production and demand for application. 
Recommendations of NPK fertilisers in Sri Lanka for different crops range from 125 to $1500 \mathrm{~kg} / \mathrm{ha}$ per season (for legumes and potato, respectively, with recommendations for other annual crops and plantation crops varying within this range) (Weerasinghe 2017). However, the usage of synthetic fertilisers in the country varies between 80 and $700 \mathrm{~kg} / \mathrm{ha}$ (as total of urea + triple super phosphate + muriate of potash) depending on the crop sector, with a national average of about $270 \mathrm{~kg} / \mathrm{ha}$. Despite various programmes the government implements, fertilisers are not equally available for all farmers. A fertiliser subsidy is given to rice farmers, yet a high variability in fertiliser usage per hectare basis can be observed among farms. Therefore, while some farmers apply adequate levels or more than the recommended levels of fertilisers for some crops, others are not applying adequate inputs to replenish the soil nutrient pool (Kendaragama et al. 2001; Kendaragama 2006). A number of socioeconomic constraints and poor agricultural extension services are causing these discrepancies. These facts reiterate the need for improving on-farm nutrient management using an integrated nutrient management approach (combining synthetic and organic fertilisers). In most of the annual cropping systems managed with synthetic fertiliser inputs, the application of $10 \mathrm{Mg}$ of organic fertiliser per hectare has been recommended (Wijewardena 2005). Compost application has been recommended for plantation crops such as rubber and coconut as well as tea (TRI 2000, 2016; Samarappuli 2001; Tennakoon and Bandara 2003).

Poor management of synthetic fertilisers in crop production systems in Sri Lanka caused a number of environmental and health issues, including contamination of surface and groundwater resources. Although highly debated yet, many allegations suggest agricultural chemicals to be the cause of increased cancer incidents and chronic kidney disease with unknown aetiology in the country. On these grounds, environmentalists campaigned for reducing the usage of fertilisers and other synthetic chemicals in the country. About $92 \%$ of the synthetic fertiliser quantity used in Sri Lanka is imported into the country. Nearly $70 \%$ of the imported fertilisers are used in rice cultivation, and this quantity is heavily subsidised (Weerahewa et al. 2010; Wijetunga and Saito 2017). Thus, the direct cost on importation of synthetic fertilisers and the virtual cost for recovering from environmental damage caused by a mismanagement of fertilisers increase the burden on the government. The development policy of the government between 2010 and 2015 targeted to reduce the import of synthetic fertilisers by $15 \%$ by 2015 by promoting the use of organic fertilisers like compost for cropping. However, this target was not achieved (Fig. 4.1). The development policy of the current government is also aiming to reduce the import of synthetic fertilisers. Government policies on the fertiliser subsidy scheme strongly influence the quantities of fertilisers imported into Sri Lanka (Weerahewa et al. 2010; Wijetunga and Saito 2017). Fertiliser imports into Sri Lanka reduced from $816,900 \mathrm{Mg}$ in 2015 to nearly $548,100 \mathrm{Mg}$ in 2017, which is about a 33\% drop. This happened in parallel to a government policy change, which is the conversion of material subsidy given to rice farmers to a cash subsidy, encouraging the use of organic and soil test-based fertilisers. However, whether the target yields are achieved with reduced fertiliser distribution and how effective the policy changes have been are yet to be analysed. 


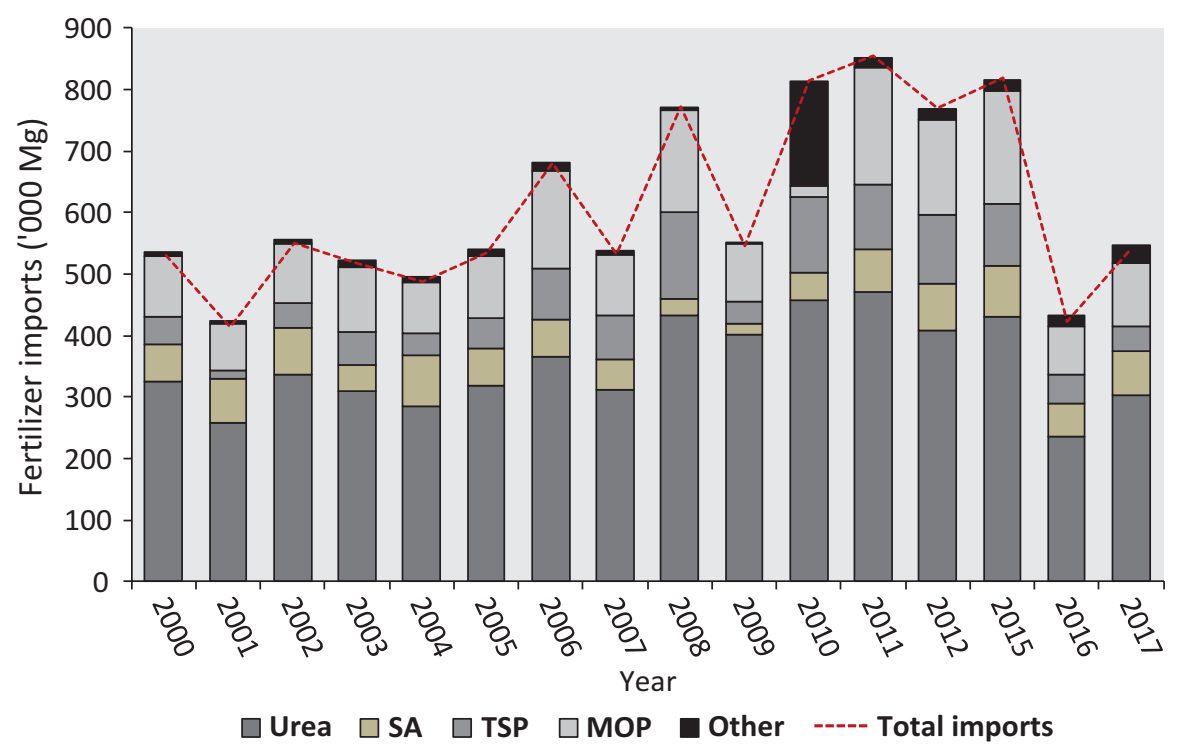

Fig. 4.1 Fertiliser imports into Sri Lanka. The fertilisers include urea, sulphate of ammonia (SA), triple super phosphate (TSP), muriate of potash (MOP), and other types (zinc sulphate, kieserite, etc.). (Source: Personal communication with National Fertilizer Secretariat in 2017)

\section{Government Initiatives to Promote Composting}

Composting in Sri Lanka first started as a method to replace the use of synthetic fertilisers with organic fertilisers in small-scale farms or at the household level. Composting provided an opportunity to recycle crop residues and farm waste, enabling farmers to recycle nutrients at the farm scale. The input materials usually composed of crop residues, cattle manure, wood ash, grass clippings, some soil or compost (as an inoculant of microorganisms), and rice straw like crop residues. Despite the intensive campaigns made by the Department of Agriculture in Sri Lanka to popularise compost production, it still remains less popular among farmers. Seasonality and spatial heterogeneity in the distribution of materials required for composting (crop residues) and labour requirement are among the reasons for the weak adoption of composting technology. In addition, indirect facts such as the high availability of chemical fertilisers on the market, the quick response the crops exhibit for chemical fertiliser applications, the requirement for compost in large quantities to improve productivity under tropical climate, and a lack of awareness about the benefits of compost for soil fertility also contribute to a weak interest in composting.

Governments since the late 1990s started to promote compost production. Therefore, the objectives for promoting compost production evolved with time: first as a method for providing an organic fertiliser source to farmers and later as a way to provide a solution for recycling organic waste generated at household level and 
in animal farms. Then, the objectives of compost production further evolved as an approach to deal with organic waste accumulated in a large scale in urban and periurban settings all the while targeting to reduce synthetic fertiliser requirements for cropping. In parallel, the scale and methods of compost production changed from small-scale at farm-field or home garden settings to large-scale composting facilities operating at commercial scale. At the same time, the nature of inputs used for compost preparation has changed and diversified. A few companies are producing compost at a large scale in the country, and several small-scale producers are also contributing to the market. However, compost still remains a popular organic fertiliser applied in the floriculture industry, nursery management, and home gardening, but not widely used in the commercial-scale cultivation of vegetables and other annual crops (Samarasinha et al. 2015).

A number of government-sponsored programmes were initiated to popularise compost production at different scales in the country and to promote organic agriculture and integrated plant nutrient management. Government programmes such as 'Pilisaru' implemented in 2008 by the Central Environmental Authority and Ministry of Environment and Renewable Energy of Sri Lanka targeted to recycle biodegradable waste at the domestic and municipal scale (Basnayake and Visvanathan 2014). The Pilisaru programme also promoted the sorting of waste into different categories as biodegradable, paper, plastic/polythene, glass, and metal before collection. Through this programme, nearly 18,000 compost bins were distributed freely among people in urban and peri-urban settings mainly, aiming to reduce the loading of waste to local authorities. Non-governmental organisations (NGOs) also distributed compost bins among households. During the same period, several private companies (e.g. Wayamba Polymers, CIC Pvt. Ltd., ARPICO Plastic Ltd.) started selling compost bins. By 2011 nearly 70,000 bins were distributed or sold to the citizens. While promoting compost production at domestic level, the Pilisaru programme also supported compost making with solid waste and largescale composting by private companies/entrepreneurs. Accordingly, 100 composting stations associated with municipal councils were established by 2011. Further, the national policy and strategy on solid waste management (SWM) in Sri Lanka were developed in 2007 and 2008, respectively. The national strategy aimed to reduce, reuse, and recycle solid waste. The reduction of waste generation was achieved only in some municipal councils (e.g. Balangoda) in the country (Samarasinha et al. 2015).

The 'Api wawamu rata nagamu' (i.e. let's grow and develop the country) programme later promoted by the Department of Agriculture of Sri Lanka as part of the development policy of Sri Lanka from 2008 to 2015 promoted home gardening using the concepts of organic agriculture and integrated plant nutrient management. This programme increased the usage of compost among people. However, the overall goal of reducing fertiliser imports into the country by promoting organic agriculture and home gardening was not achieved due to several reasons. Although the Pilisaru project promoted the establishment of small- to medium-scale compost production centres in association with solid waste collecting units of municipal 
councils, the marketing structure for the produce was not clearly defined. Therefore, composting MSW has become a burden rather than an income-generating activity (Samarasinha et al. 2015). Further, lack of sorting waste before disposal increased labour requirement for processing compost as well as reduced the quality of compost (Samarasinha et al. 2015). Due to bad odour of decomposing waste, mixing of leachate coming out during composting to surface water and groundwater, and increased density of wild animals (e.g. stray dogs, crows, etc.) and flies, the composting centres were not well-received by people in some regions (Premachandra 2006; Samarasinha et al. 2015). Protests against composting centres were common when they were located in densely populated areas. As a result, people were not motivated to develop composting as a business in many instances, and the compost produced was not effectively used.

The policy documents of the government after 2015 also advocate for the use of organic fertilisers. State patronage was proposed to be provided to produce pest control liquids or powder utilising indigenous herbal extracts, and initiate measures to formulate a time frame for the gradual elimination of the use of chemical fertilisers and agro-chemicals. In the government's 8-year economic development plan 'Vision 2025 - A Country Enriched' (2017), the forethought for developing national policy on food quality and the use of permitted levels of fertilisers, increasing the share of organic products in the market, and improving solid waste management strategies were stated. Providing a material subsidy (synthetic fertilisers) discouraged farmers to use organic fertilisers (Weerahewa et al. 2010; Wijetunga and Saito 2017); thus, in 2017, a cash subsidy was given with the hope that this would increase the practice of organic agriculture and use of compost. Although this resulted in a clear decline in the importation (Fig. 4.1) and usage of synthetic fertilisers, the target of promoting compost application was not satisfied. The government policies shifted from a cash subsidy scheme to a material subsidy scheme again in late 2018 . The highly dynamic socio-political environment of the country is not supportive of implementing the decisions and achieving the visions stated in the policy documents.

\subsection{Standardisation and Recent Changes}

Since 2017 a strong drive is evident in the country to sort garbage prior to disposal, and that has seen success in many places. Sorting garbage at the domestic level helps to reduce labour requirement and improve efficiency of MSW compost preparation (Samarasinha et al. 2015). With the increased availability of compost produced by different entities at different scales in the market, the need for controlling quality was highlighted. The standards for compost produced from MSW and agricultural waste were introduced in 2003 (SLSI 1246: 2003) by the Sri Lanka Standards Institution (Table 4.1). Packaging and marking standards were also established. However, there is a great need for revisiting the set of standards developed to ensure the quality and safety of products because the nature of materials used for 
Table 4.1 Standards for compost produced from MSW and agricultural waste

\begin{tabular}{|c|c|}
\hline Parameter & Threshold values \\
\hline \multicolumn{2}{|l|}{ Physical requirement } \\
\hline Moisture (\%) & $<25$ (dry weight) \\
\hline Colour & Brown/grey to dark black \\
\hline Keeping quality & $\begin{array}{l}\text { Should be able to store in prescribed package condition under } \\
\text { room temperature for } 12 \text { months }\end{array}$ \\
\hline Odour & Shall not have any unpleasant odour \\
\hline Sand content $(\%)$ & $<10$ (dry weight) \\
\hline $\begin{array}{l}\text { Residue (>4 mm particles) } \\
(\%)\end{array}$ & $<2$ (dry weight) \\
\hline \multicolumn{2}{|l|}{ Chemical requirement } \\
\hline $\mathrm{pH}$ & $6.5-8.5$ \\
\hline \multicolumn{2}{|l|}{ Total nutrient contents (\%) } \\
\hline Organic carbon & $>20.0$ \\
\hline Nitrogen & $>1.0$ \\
\hline Phosphorus as $\mathrm{P}_{2} \mathrm{O}_{5}$ & $>0.5$ \\
\hline Potassium as $\mathrm{K}_{2} \mathrm{O}$ & $>1.0$ \\
\hline Magnesium as $\mathrm{MgO}$ & $>0.5$ \\
\hline Calcium as $\mathrm{CaO}$ & $>0.7$ \\
\hline $\mathrm{C}: \mathrm{N}$ ratio & $10-25$ \\
\hline \multicolumn{2}{|l|}{ Heavy metals (ppm) } \\
\hline $\mathrm{Cd}$ & $<10$ \\
\hline $\mathrm{Cr}$ & $<1000$ \\
\hline $\mathrm{Cu}$ & $<400$ \\
\hline $\mathrm{Pb}$ & $<250$ \\
\hline $\mathrm{Hg}$ & $<02$ \\
\hline $\mathrm{Ni}$ & $<100$ \\
\hline $\mathrm{Zn}$ & $<1000$ \\
\hline \multicolumn{2}{|l|}{ Biological requirement } \\
\hline Viable weed seeds & $<16$ viable weed seeds $/ \mathrm{m}^{2}$ \\
\hline \multicolumn{2}{|l|}{ Microbiological requirement } \\
\hline Faecal coliforms per $\mathrm{g}$ & Free \\
\hline Salmonella per $25 \mathrm{~g}$ & Free \\
\hline
\end{tabular}

Source: Sri Lanka Standard Institution (2003)

composting and the scale of operations diversify to a great length since its introduction (Table 4.2). Especially composting unsorted MSW, which consists of a wide variety of materials (Fig. 4.2), introduces a number of concerns regarding the quality and safety of the compost produced as discussed later in this chapter. Accordingly, the quality standards are being revised, and a draft document was made available for the public to comment in August 2017. 
Table 4.2 Changes in commonly used material for composting and scale of operation with time

\begin{tabular}{|c|c|c|c|}
\hline Period & Scale(s) of operation ${ }^{\mathrm{a}}$ & Commonly used materials & Methods of composting \\
\hline $\begin{array}{l}\text { Before } \\
1990 \mathrm{~s}\end{array}$ & $\begin{array}{l}\text { Small scale at } \\
\text { domestic level }\end{array}$ & Household and garden waste & Small pits/heaps, bins \\
\hline \multirow[t]{2}{*}{$\begin{array}{l}1990 \text { to } \\
2007\end{array}$} & $\begin{array}{l}\text { Small scale at } \\
\text { domestic level }\end{array}$ & \multirow{2}{*}{$\begin{array}{l}\text { Household and garden waste, } \\
\text { agricultural waste (crop residues, } \\
\text { cattle manure) }\end{array}$} & \multirow[t]{2}{*}{$\begin{array}{l}\text { Bins, small heaps/ } \\
\text { windrows }\end{array}$} \\
\hline & $\begin{array}{l}\text { Small scale by } \\
\text { agri-businesses }\end{array}$ & & \\
\hline \multirow[t]{2}{*}{$\begin{array}{l}\text { After } \\
2007\end{array}$} & $\begin{array}{l}\text { Small scale at } \\
\text { domestic level }\end{array}$ & \multirow{2}{*}{$\begin{array}{l}\text { Household and garden waste, } \\
\text { agro-industry waste (crop } \\
\text { residues, cattle manure, poultry } \\
\text { manure), ash from dendro-power } \\
\text { plants, MSW from urban and } \\
\text { peri-urban settings, night soil }\end{array}$} & $\begin{array}{l}\text { Domestic scale: bins, small } \\
\text { heaps }\end{array}$ \\
\hline & $\begin{array}{l}\text { Small and medium } \\
\text { scale by agri- } \\
\text { businesses, some } \\
\text { municipal councils, } \\
\text { and a few companies }\end{array}$ & & $\begin{array}{l}\text { Small to medium } \\
\text { commercial scale: } \\
\text { windrows, semi-aerobic } \\
\text { trench, in-vessel } \\
\text { composting (e.g. inclined } \\
\text { step-grate composter) }\end{array}$ \\
\hline
\end{tabular}

${ }^{a}$ The scale of operation of the business is defined by the capacity of handling organic waste per day: small scale, less than $10 \mathrm{MT} /$ day; medium scale, 10-50 MT/day

\subsection{Stakeholder Involvement: Good Practice Examples}

Establishing composting as a profitable business can be achieved only if all stakeholder groups are involved in developing the process (Sinnathamby et al. 2016). Composting centres at Balangoda and Weligama municipalities are examples of successfully operating facilities that produce compost using MSW in Sri Lanka (Samarasinha et al. 2015).

\section{Balangoda Composting Facility}

This centre was established with the financial support of the World Bank, Provincial Government, Chief Minister of the provincial council, and the Central Environmental Authority of Sri Lanka (under Pilisaru project). Some key traits that made the Balangoda composting facility a successful operation are indicated here:

- Using waste that is in the early stage of decomposition - waste collection is being practised on a daily basis in the morning hours

- Involving key stakeholders in the process - local municipal council involved schools in the region and conducted special programmes with the involvement of key stakeholders in the region generating solid waste to promote reducing and recycling waste. As a result, the amount of waste generated reduced remarkably, and people practise sorting of waste as per the instructions which helped to reduce labour requirement for compost production

- Taxing people or entities generating mixed waste

- Not collecting hospital waste for compost making 


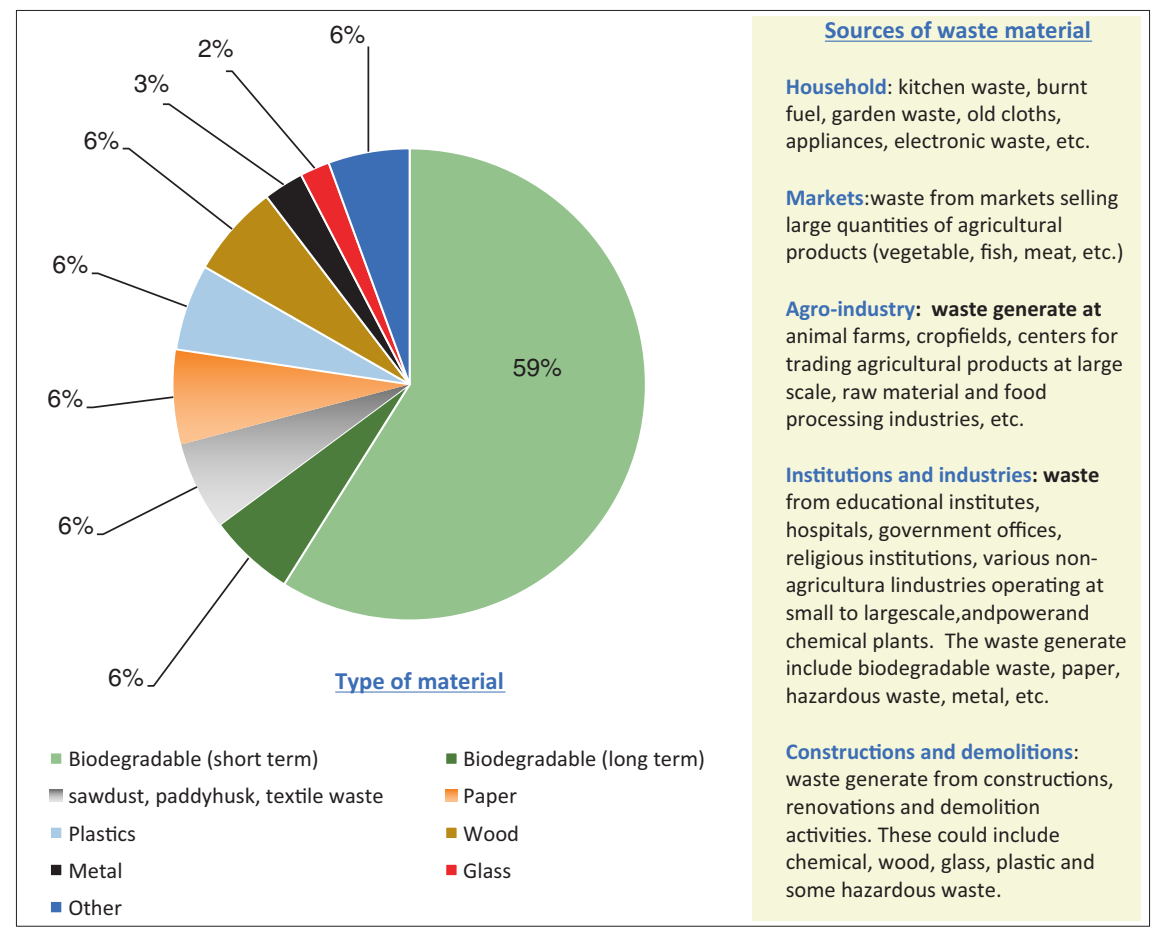

Fig. 4.2 Composition of solid waste generated in Sri Lanka. (Developed based on information from Arachchi 2016 and Samarasinha et al. 2015)

- Using skilled labour in the composting centre - workers are required to have a certificate from the National Vocational Training Institute. This improved the social recognition and dignity of the workers

- Addition of biochar to improve the quality of compost

- Regular quality testing of the produce

- Managing the quality and quantity of the leachate released to the environment the centre uses diluted leachate to wet windrows and by that reduced the quantity released to the environment. Further leachate is treated before release

- Taking actions to ensure safety of workers - the centre provides safety gears to wear during compost production and performs regular health checks of the workers

So far, the compost produced has been marketed successfully although some improvement is needed in this regard. 


\section{Weligama Composting Centre}

This facility was established with funds from the Ministry of Provincial Government and a few NGOs. It is being operated successfully using similar strategies as in the Balangoda composting centre (Samarasinha et al. 2015; Sinnathamby et al. 2016).

Both composting centres in Balangoda and Weligama were well-accepted by the people in those regions. These centres generated income that helped to improve infrastructure facilities in the respective areas and created a positive impact on the social and economic wellbeing of the people. Similar characteristics are seen in other successfully operating composting centres associated with local authorities (Samarasinha et al. 2015; Sinnathamby et al. 2016).

These facilities can be further improved in relation to the quality and safety of compost produced and establishment of marketing linkages with end users. In addition to biodegradable agro-industry waste, night soil that comprise of human faeces collected from septic tanks, slaughterhouse wastes, and animal farm wastes are being collected and used for compost production in these centres. Septic waste, farm waste, and slaughterhouse waste are though potential sources of contaminants such as pathogens. The quality and safety of compost produced can be improved if the pathogen-free waste stream is separated from the highly pathogen-contaminated waste stream when producing compost (Hamer 2003). This would enable the establishment of separate treatment steps to handle pathogen-contaminated waste prior to its use in compost preparation or being released directly to the environment facilitating safe disposal. More policy-level interventions are needed, and facilities should be developed with public-private partnership to regulate safe disposal and/or recycling of electronic waste which is the source of most of the toxic trace elements in solid waste (Sinnathamby et al. 2016; Franchetti 2017).

\section{Safety Concerns Raised by the Major Raw Materials Used}

Due to the push for recycling solid waste and a poor understanding of quality and safety concerns, many commercial-scale compost producers tend to use any biodegradable material that they can find conveniently in their composters. Constituents of compost are largely determined by what is being used as the raw material during production. Any biodegradable material could be composted. But if source materials and the composting process are not carefully regulated, whether the end product is going to meet the quality and safety standards cannot be guaranteed. Table 4.3 presents some of the most popular materials used in compost making. All the raw materials listed therein are being used to different degrees by the composters in Sri Lanka. Among these, poultry manure and MSW are the most widely used raw material by large-scale composters in Sri Lanka. The heterogeneity of unsorted waste used for composting at medium- and large-scale operations poses a great challenge for managing safety and hygiene of the process as well as the quality and safety of the compost produced (Samarasinha et al. 2015). Poultry manure is also a popular material used in composting by small- to medium-scale compost producers. The 
Table 4.3 Widely used raw materials for compost making and concerns raised due to composition

\begin{tabular}{|c|c|c|}
\hline Raw material(s) & Major concern(s) & References \\
\hline $\begin{array}{l}\text { Municipal solid } \\
\text { waste }\end{array}$ & $\begin{array}{l}\text { MSW contains mixture of waste materials } \\
\text { containing plastics and hazardous waste in addition } \\
\text { to biodegradable organic waste. Compost could } \\
\text { have potentially toxic trace elements, micro- and } \\
\text { nano-plastics, antibiotic resistance determinants, } \\
\text { pathogens, bio-aerosols, and inorganic and organic } \\
\text { pollutants. These constituents could harm workers } \\
\text { during compost preparation and easily spread in the } \\
\text { environment during composting }\end{array}$ & $\begin{array}{l}\text { Smith (2018), Riber } \\
\text { et al. (2014), and } \\
\text { Samarasinha et al. } \\
\text { (2015) }\end{array}$ \\
\hline Animal manure & $\begin{array}{l}\text { Farmyard wastes could include used bedding } \\
\text { materials, faeces, and feed residues. These could } \\
\text { harbour antibiotic resistance determinants (chemical } \\
\text { residues and genetic information required to acquire } \\
\text { resistance), pathogens, and parasites of animals and } \\
\text { humans and could contaminate compost depending } \\
\text { on characteristics of composting process. These } \\
\text { constituents could harm workers during compost } \\
\text { preparation and easily spread in the environment } \\
\text { during composting }\end{array}$ & $\begin{array}{l}\text { Diarrassouba et al. } \\
\text { (2007), Dolliver et al. } \\
\text { (2008), Furtula et al. } \\
\text { (2010), Riber et al. } \\
\text { (2014), Herath et al. } \\
\text { (2015), and Herath } \\
\text { (2017) }\end{array}$ \\
\hline $\begin{array}{l}\text { Crop residues and } \\
\text { agricultural waste } \\
\text { from markets }\end{array}$ & $\begin{array}{l}\text { Crop residues collected from fields and agricultural } \\
\text { waste could contain plant pathogens and weed } \\
\text { seeds. Poor-quality compost prepared with these } \\
\text { materials could lead to pest infestation }\end{array}$ & Dorahy et al. (2009) \\
\hline $\begin{array}{l}\text { Slaughterhouse } \\
\text { waste }\end{array}$ & $\begin{array}{l}\text { Slaughterhouse waste may contain potential human } \\
\text { and animal pathogens. These constituents could } \\
\text { harm workers during compost preparation and } \\
\text { easily spread in the environment during composting }\end{array}$ & $\begin{array}{l}\text { Franke-Whittle and } \\
\text { Insam (2013) }\end{array}$ \\
\hline $\begin{array}{l}\text { Fly ash from } \\
\text { power plants }\end{array}$ & $\begin{array}{l}\text { Fly ash sometimes could enhance the mobility of } \\
\text { potentially toxic trace elements in compost }\end{array}$ & $\begin{array}{l}\text { Ram and Masto } \\
(2014)\end{array}$ \\
\hline Human faeces & $\begin{array}{l}\text { Human faeces could harbour pathogens and } \\
\text { parasites and antibiotic resistance determinants and } \\
\text { organic pollutants. These constituents could harm } \\
\text { workers during compost preparation and easily } \\
\text { spread in the environment during composting }\end{array}$ & Pruden et al. (2013) \\
\hline
\end{tabular}

nature of the raw material makes this compost a cheap solution that can be made abundantly available. The major risks posed by some of the key materials used in composting are briefly discussed in the next few subsections.

\subsection{Making Compost out of MSW: Opportunity Versus Challenges}

Municipal solid waste is a popular choice of input in large-scale compost production in many countries, and composting MSW is often done by government-owned/ government-sponsored composting facilities and sometimes by private companies. 
In the United States, solid waste collection is sub-contracted to private businesses, which saves money for the government for handling waste while promoting recycling and reusing of materials (Walls 2005). Solid waste management in many countries is practised successfully with partnerships between government, industry, and universities (Walls 2005; da Cruz et al. 2014; Franchetti 2017). In Sri Lanka, collection of MSW and composting of these materials are mainly conducted by local government authorities. The opportunities versus challenges in composting MSW in Sri Lanka are discussed in the following paragraphs considering this context.

Solid waste generation, which is estimated to be at 6,400 MT/day, has led to a number of issues with respect to resource management (Basnayake and Visvanathan 2014; Arachchi 2016). Unsafe disposal of waste, pollution of environment due to bad management practices at waste disposal sites, and unceremonious dumping of waste in improper locations have created a number of socioeconomic and health issues. In Sri Lanka, the common non-biodegradable waste materials such as glass, plastics, metals, coconut shells, and textile have a secondary market. Hence, such materials are collected separately by local vendors. Further, some municipalities collect biodegradable and non-biodegradable waste separately. They use biodegradable waste in composting, sort the non-biodegradable waste for recycling, and use the rest of it in landfills. The biodegradable waste in MSW has been observed to range between 30 and $75 \%$ in different regions; and this percentage is highly influenced by the type of waste collection systems in operation as well as by the effectiveness of waste recycling and reuse programmes (Basnayake and Visvanathan 2014; Arachchi 2016; Samarasinha et al. 2015). Waste collection by local authorities is estimated as 2,680 MT/day and constitutes about $62 \%$ of biodegradable materials on average (Basnayake and Visvanathan 2014; Arachchi 2016); thus, there is a great opportunity to recycle nutrients back to agricultural systems (Samarasinha et al. 2015). However, there are many challenges to overcome. Most of the challenges are due to the less organised MSW management structure within the country, starting with the lack of sorting. Key challenges are discussed in the following paragraphs.

According to the Municipal Council Ordinance Sections 129, 130, and 131, the Urban Council Ordinance Sections 118, 119, and 120; and Pradesheya Saba Act No. 15 of 1987, Sections 93 and 94, in Sri Lanka, all waste collected by local authorities including street refuse and house refuse become properties of the council, and full power to sell or dispose these materials lies with the council (Arachchi 2016). Thus, the management of solid waste has become a strict business of the local government. Local government authorities often do not have enough financial strength to develop fully equipped composting centres as income-generating entities (Sinnathamby et al. 2016). Policies and regulations are not in place to encourage private companies to engage in solid waste management.

At present, the separation of biodegradable waste according to the type at solid waste collection centres is not practised. Therefore, hazardous and biomedical waste, household waste, farm wastes, and sometimes sewage/septic waste and night soil are collected altogether as MSW (Premachandra 2006; Arachchi 2016). 


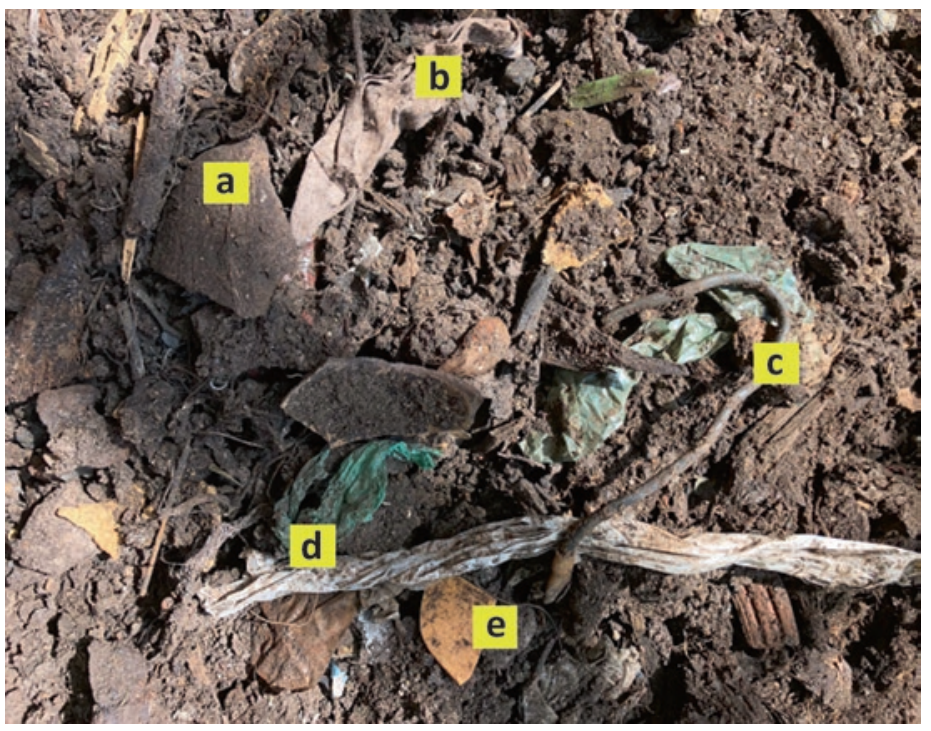

Fig. 4.3 A sample of MSW-based compost just before sieving. This compost contained nonbiodegradable materials such as (a) pericarps of fruits that are hard to decompose, (b) textile materials, (c) wires, (d) polythene, (e) leather, etc. that would end up in a rejected pile after sieving. (Photo credit: Dandeniya)

Receiving unsorted mixed waste as the starting material is the biggest challenge for composting MSW (Basnayake and Visvanathan 2014). In addition to hazardous and biomedical waste such as batteries, small electronic appliances, and hospital waste that could release potentially harmful organic and inorganic contaminants to the compost, non-biodegradable materials like plastics, textile, and polythene are also present in large volumes in MSW (Hamer 2003; Arachchi 2016). These nonbiodegradable materials will increase the pile of rejected materials at the end of the composting process (Fig. 4.3). Storing the rejected pile has become a great challenge for effective space management in composting facilities (Samarasinha et al. 2015).

Most of the municipalities collect waste once or twice a week mainly due to resource limitations for handling waste. Therefore, by the time waste is being collected, anaerobic digestion has started in polythene bags, which are commonly used for storing biodegradable waste (Samarasinha et al. 2015). Thus, not collecting waste during the early stage of decomposition leads to difficulties in sorting materials and handling of solid waste during composting, sometimes encouraging growth of harmful microorganisms and development of bio-aerosols and volatile chemicals that could be harmful for the handlers. Moreover, very often the waste collected by local authorities contains more moisture than the optimum level for composting. This results in production of a leachate during the composting process, which creates many problems such as pollution of surface and groundwater, skin irritation of people working in composting facilities, bad odour, and fly infestations. 
Inconsistency in the quality of compost produced, safety concerns in handling materials and of the end product, high labour demand to sort materials prior to composting, and requirement of special infrastructure facilities to handle waste are some examples of challenges faced by compost producers when using moist mixed waste.

In 2017, people in the Badulla municipality in Sri Lanka protested against dumping septic tank waste to solid waste collection areas located within the city periphery in close proximity of schools and the general hospital. Collecting night soil as solid waste is a common practice in all local authorities of municipal councils in Sri Lanka and in other countries (Hamer 2003; Samarasinha et al. 2015). Not considering the suitability of land for collecting solid waste and establishing compost production units has also created several problems. The nature of land and its proximity to dense habitats are important when developing mechanisms to manage leachate, flies, and stray animals. Neglecting the views of local authorities when developing national-level strategies for waste management often leads to unsuccessful projects.

\subsection{Poultry Litter/Manure as Raw Material for Composting and Its Associated Challenges}

Poultry represents about one-fourth of the meat produced globally (Apata 2012). Chicken meat is a widely used protein source for human nutrition. With the growth of middle-class Sri Lankan society, a clear shift in food habits took place - from a low-protein to a high-protein content diet. Increased propaganda and accessibility of meat-based products and eggs and enhanced purchasing power of consumers blessed the poultry industry in the country with a high year-round demand. As a result, a number of poultry farms in small, medium, and large scales started in the country. In intensive production units, broiler chicken is produced in less than 6 weeks (Gerber et al. 2007); hence, one flock of birds leave the farm every 36 42 days, and in parallel, the bedding material containing bird droppings and feed residues should be removed. One major problem faced by the poultry farmers in the country is waste management.

In broiler farms, one popular solution is to sell or provide free dispatch farmyard waste (hereafter referred to as poultry litter) to crop farmers and compost producers (Herath et al. 2015). Practice requires that poultry litter is piled on land and allowed to mature for a couple of months and sold or used for cultivation of crops as an organic fertiliser or used as a raw material in compost production (Herath et al. 2015). This matured poultry litter is called poultry manure, or farmers sometimes refer to it as composted poultry manure although the process undertaken does not follow a proper composting technique. Poultry litter/manure is a popular low-cost raw material highly available for composting. In addition to nutrients, poultry litter/ manure adds volume to the compost because the material contains paddy husk or sawdust which takes a long time to degrade and thus makes the compost available to the market on regular shorter cycles. Non-standardised manure and improperly 
generated compost procedures are causes of public health concerns which have not been considered in the past and that are going behind the pathogen or heavy metal concentration. Poultry litter/manure is a source of antibiotic resistance determinants and, therefore, imposes a silent threat to environmental quality and health (Herath et al. 2016). The environmental concerns from using these materials are not as visible in the short run as those from MSW. Hence, the general public and composters are mostly unaware about the challenges and threats associated with using poultry litter/manure in compost making.

The poultry industry practises genetic selection, improved feeding, and health management practices to increase production to meet the growing demand for meat and eggs. Antibiotics are extensively used in the poultry industry at sub-therapeutic dosages along with feed and water as a prophylactic method (Gerber et al. 2007; Apata 2012; Herath et al. 2015). The intensive use of antibiotics in animal husbandry leads to the establishment of a pool of antibiotic-resistant genes in the environment (Pruden et al. 2013). This has been observed in the Sri Lankan case as well (Herath et al. 2015; Herath 2017). The use of fluoroquinolone antibiotics in broiler chickens has caused an emergence of resistant Campylobacter in poultry (Randall et al. 2003). The extensive use of tetracycline in large-scale poultry production units in Sri Lanka has led to high levels of resistance development among bacteria rendering tetracycline no longer effective in disease control on those farms (Dandeniya et al. 2018). The tetracycline-resistant bacteria populations (10 ppm tetracycline) in poultry litter collected from those farms were as high as $9.88 \pm 0.47 \log _{10} \mathrm{CFU} / \mathrm{g}$, and the enrofloxacin-resistant populations (10 ppm enrofloxacin) were around $9.13 \pm 0.50 \log _{10} \mathrm{CFU} / \mathrm{g}$ (when total culturable bacteria population size was $11.54 \pm 0.49)$. The populations of tetracycline- and enrofloxacin-resistant bacteria (10 ppm concentration) in medium-scale poultry farms were $4.26 \pm 0.46$ and $2.97 \pm 0.42 \log _{10} \mathrm{CFU} / \mathrm{g}$, respectively (when total culturable bacteria population size was $6.73 \pm 0.52$ ). Therefore, it is not surprising if the poultry practitioners of large-scale farms would have to abandon the use of enrofloxacin in the near future considering the level of resistance building up. Majority of the bacteria isolates obtained from these farms showed minimum inhibitory concentration and minimum bactericidal concentrations (MIC and $\mathrm{MBC}$ ) for tetracycline greater than $128 \mathrm{ppm}$, and a significant proportion had values exceeding $1024 \mathrm{ppm}$. These results suggest an acquired resistance towards tetracycline through horizontal gene transfer events in bacteria, which has strong implications on the spread of antimicrobial resistance in the environment. The most commonly used antibiotics in broiler farms in Sri Lanka representing both medium- and large-scale operations are presented in Fig. 4.4.

Most of the antimicrobials and some antibiotic-resistant gut flora end up in waste products generated from poultry production including poultry litter (Diarrassouba et al. 2007; Herath et al. 2015; Chen and Jiang 2014). Nearly 3 to 60\% of antibiotics administered to an animal is excreted back through litter, and the concentrations in litter could range from 0.2 to $66 \mathrm{mg} / \mathrm{kg}$ (Diarrassouba et al. 2007; Furtula et al. 2010). Both antibiotic residues and antibiotic-resistant gene pool that end up in poultry litter could serve as antibiotic resistance determinants in the environment. 
Types of antibiotics used in farms associated with large-scale companies

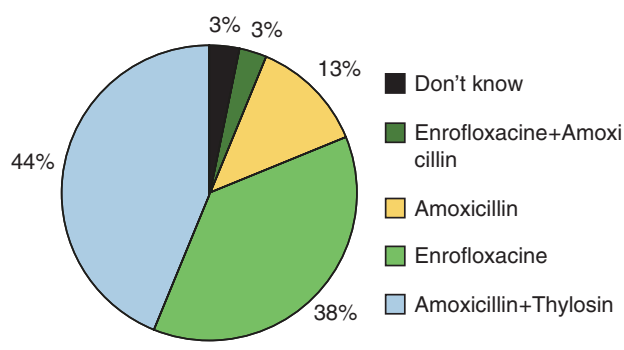

Types of antibiotics used in medium scale farms that sell produce locally

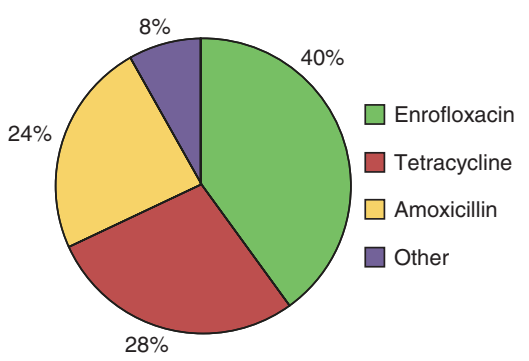

Fig. 4.4 Most commonly used antibiotics in broiler farms managed in large and medium scales in Sri Lanka. (Source: Dandeniya et al. 2018)

During the composting process, microbial community structure shifts mostly due to changes in abiotic factors such as $\mathrm{pH}$, temperature, and the duration it prevails at a certain range and moisture level (Kim et al. 2009). Due to heat generation in the composting process, most of the pathogens are eliminated. In addition, microbial antagonism, production of organic acids, $\mathrm{pH}$ change, desiccation, starvation stresses, exposure to ammonia emission, and competition for nutrients also inactivate pathogens (Wilkinson et al. 2011). Applying heat treatment after or before composting is a technique that reduces or eliminates potential bacterial pathogens in animal wastes (Chen and Jiang 2014; Herath et al. 2015).

Composting is divided into four main phases based on temperature and the active microbial community, namely, mesophilic, thermophilic, cooling, and maturation phases. In the aerobic microbial decomposition phase, heat is generated, increasing the temperature of compost mixtures to the thermophilic zone $\left(45\right.$ to $\left.75^{\circ} \mathrm{C}\right)$. These temperatures can cause death of mesophilic pathogens such as Escherichia coli O157:H7 and Salmonella sp. (Ryckeboer et al. 2003). Chen and Jiang (2014) observed that during the curing of poultry litter to form poultry manure, the temperatures inside the poultry litter pile change to some extent during composting. Therefore, depending on the maturity of poultry manure, the species composition of microbial communities and, thus, the abundance of antibiotic resistance bacteria can be expected to change (Herath et al. 2015).

The survival of bacteria resistant to $100 \mathrm{ppm}$ of tetracycline was observed even after subjecting broiler litter to $80{ }^{\circ} \mathrm{C}$ heat for $24 \mathrm{~h}$ (Herath 2017). Thus, there is a possibility that antibiotic-resistant bacteria could survive the composting process, especially when poultry litter is composted. The risk is high when the temperature rise during composting is uneven and does not reach values above $60{ }^{\circ} \mathrm{C}$ (Herath 2017). In addition to differences in relation to the maturity of manure, differences were observed in antibiotic-resistant communities with respect to intensity of management (large- to medium- to small-scale production units) and type of target production (layer farms vs. broiler farms) as well (Herath 2017; Dandeniya et al. 2018).

When poultry manure or so-called composted poultry manure is produced by farmers at small scale by just piling up the poultry litter to mature, it increases the 
risk of spreading antimicrobial resistance due to two reasons. Firstly, the temperature inside the pile will not reach thermophilic stage. Maturing the pile at a temperature below $40{ }^{\circ} \mathrm{C}$ would lead to the proliferation of pathogenic and enteric bacteria (high-risk group carrying antibiotic resistance genetic elements) in the pile, instead of reducing pathogenic and harmful bacteria (Herath et al. 2015). Further, the piles are not covered or sheltered; hence, they are directly exposed to rainfall. As a result, the antibiotic resistance determinants could spread through the leachate and runoff from the pile. When the poultry litter/manure is used by medium- to large-scale compost production units, the windrow system is often used with proper composting techniques. These systems could contribute to a spread in antibiotic resistance determinants in the environment if temperature regulation and leachate and runoff control have not been attended to properly.

\subsection{Challenges Associated with Composting Cattle Manure}

Cattle manure is traditionally used in compost preparation, especially under smallholder settings. Cattle management in Sri Lanka is mainly practised for milk production in a less intensive scale. Rearing of cattle is mostly practised free-range. Sheltered rearing is practised only in some regions, and very often those farms are operated at a small scale and scattered in the rural areas. Therefore, collecting cattle manure in adequate quantities for compost making at medium or large scales is a challenge. Only a few farms exist where cattle are reared in large scale intensively. Those farms mainly recycle cattle manure in their pasture fields. Because of these reasons, cattle manure is used as a raw material only when composting is practised in small scale.

Antibiotic use in cattle farms is less intensive as compared to that in the poultry industry. So far, no structured study has been reported in Sri Lanka on antibioticresistant bacteria introduced by cattle manure to compost nor has the potential for surviving the abiotic composting process been demonstrated. Nevertheless, this does not mean that the risk might not exist for cattle manure. In other countries, $E$. coli was instead found as the bacteria that better resisted the thermic temperatures, especially if the time for compost maturation was not respected. Tetracycline resistance genes were the genes most commonly found, and studies (Sharma et al. 2009) revealed that the gene levels are not affected by the composting process. It would be indeed important for risk assessment to identify the resistant bacteria surviving the composting process and their survival in the environment following land application. 


\subsection{Human Faeces as a Source of Raw Material in Composting}

Night soil and septic waste are often dumped at MSW collecting locations in some municipalities along with other waste, without any separation (Samarasinha et al. 2015). Thus, human faeces have automatically become a raw material in the MSW composting process. Historical records indicate the use of human faeces in crop nutrient management in ancient Egyptian and Chinese civilisations. However, no such records exist in traditional agriculture in Sri Lanka. Social reception towards products that use human faeces as a raw material remains poor in the country. At present, the possibility of producing compost using human faeces is being researched by a group of scientists in Wayamba University of Sri Lanka with the financial support from the International Water Management Institute (IWMI 2018). The researchers seek to address the problem of managing sewage waste generated from households and unsafe disposal of night soil and septic waste. However, organic pollutants introduced with detergents and antibiotic resistance determinants and pathogens surviving in night soil and septic waste and the fate of these constituents during composting have not been studied extensively in Sri Lanka and would require more attention in the future.

Considering the popularity and availability of antibiotics for managing diseases, it is important to investigate the development of antibiotic resistance through all possible means. Recent medical surveys in the country indicated that one in three antibiotic prescriptions given to patients is an unnecessary directive, contributing to widespread misuse of antibiotics. Antibiotics such as amoxicillin, ampicillin, and Augmentin can be easily purchased from drugstores. Although there are regulations requiring prescriptions, these are not being practised. The misuse of common antibiotics is very high. An increase in antibiotic resistance development and the occurrence of multiple drug resistance have been observed in hospital settings (Liyanapathirana and Thevanesam 2016). This is an area that needs due attention since almost all municipalities producing compost using solid waste in Sri Lanka are not segregating materials based on their biological safety. While improving the composting process to lower the risks of spreading pathogens and antibiotic resistance determinants with the use of human faeces, attention should also be given to the study of the safety of the production process and the final product itself. Therefore, quality assessments should go beyond the set standards for compost. A revision of quality standards for compost based on the risk of resistant pathogens and antimicrobial resistance spread in the environment or risks for food chain contamination is recommended when scientific evidence reaches a critical mass. For the moment, precautionary measure should be undertaken, especially in the frame of food chain production. 


\section{Environmental Impact: Status and the Way Forward}

The quality or the environmental significance of compost is a relative concept that should be viewed considering the target application. The primary objective of applying compost to crop fields is to supply nutrients; thus, it is considered as an organic fertiliser. In addition, there can be different objectives such as use as landfill material, nutrient source for plants in reclamation sites/non-food crops, and use as soil amendment to improve long-term soil fertility aspects (Hurst et al. 2005; Smith 2009; Agegnehu et al. 2015). When producing compost to achieve these secondary objectives, the nature of materials used and quality and safety concerns during production and later use would vary. Hence, to better evaluate quality concerns, a tailor-made set of regulations and quality standards should be made available separately for the composting process and the produce targeted for different purposes (e.g. organic fertiliser, soil fertility enhancer, landfill material, fertiliser for reclamation site, etc.). This can be achieved via identifying a set of common core standards and regulations across all the targeted applications and specific conditions to relax or fulfil when the target end use is factored in. This is already being practised in some countries. A good-quality compost should be able to support plant growth by supplying nutrients and not pollute the environment by any means. It should be adequately matured, should contain nutrients and moisture in acceptable levels, should be free from pathogens and weed seeds, and should have acceptable shelf life. The acceptable values could vary from country to country and also be based on the targeted application. Presently in Sri Lanka, there is only a single set of standards for compost irrespective of the intended end use (Table 4.1).

\subsection{Impact on Soil Environment}

Compost contains chemicals (nutrients as well as pollutants) in different forms ranging from simple inorganic ions to complex organic forms contributing to different pools of nutrients in soil, namely, plant-available pool in soil solution, readily exchangeable pool, and reserves. Compost releases nutrients to the plant-available pool slowly at a pace close to the rate of plant nutrient uptake. Therefore, unlike chemical fertilisers, that enrich the plant-available pool for a short term, compost supports retention of nutrients in the soil system avoiding leakage (Fig. 4.5). Depending on the type of compost, its contribution to different pools of nutrients in soils varies (Agegnehu et al. 2015). While compost produced with the objective of using it as a soil amendment to improve long-term soil fertility contributes mostly to nutrient reserves, compost produced as an organic fertiliser contributes mostly to the exchangeable fraction (Fig. 4.5). The same phenomena hold true for the pollutants in compost, and some pollutants introduced to soil via compost could move through the food chain, while some other forms could remain in soil for a long duration. In addition to chemical constituents, compost also contains organisms 


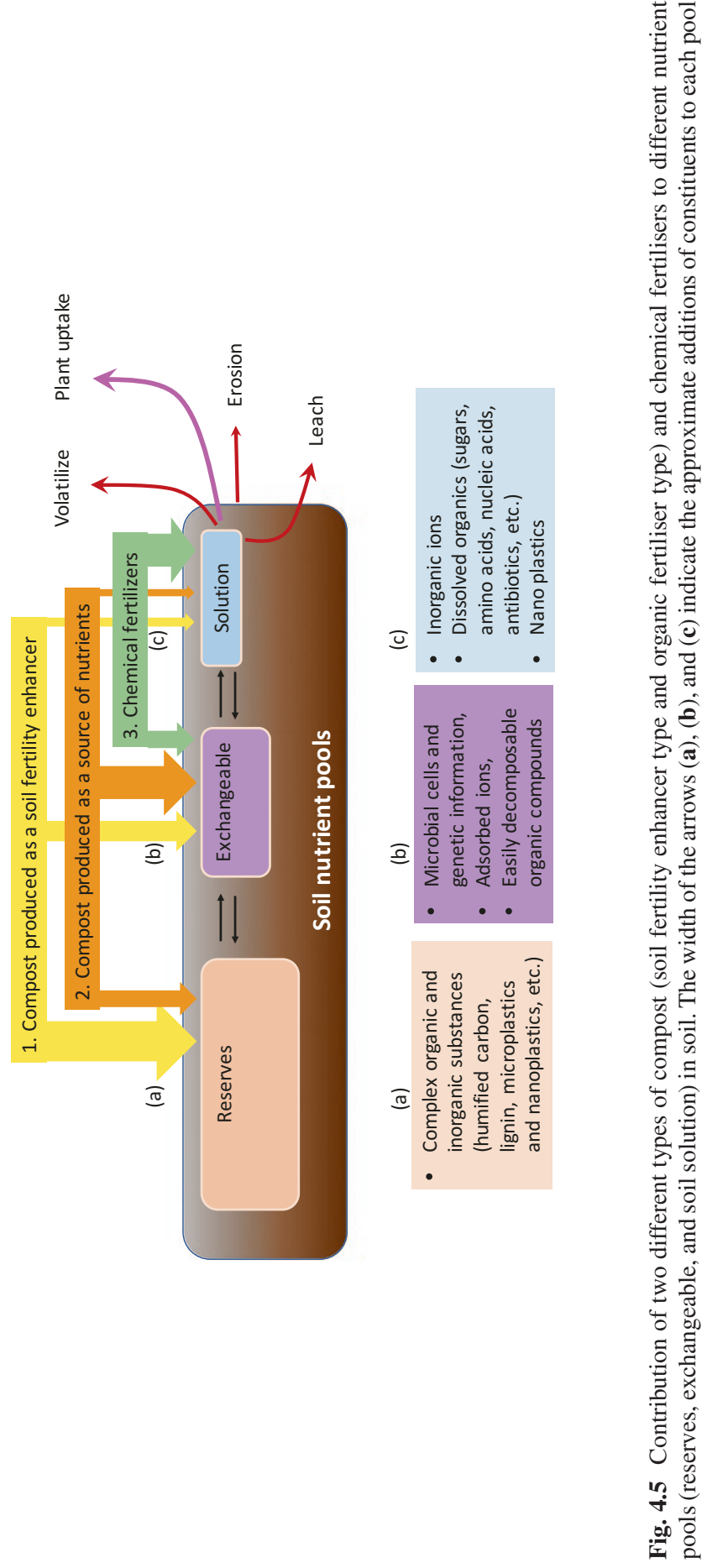


(bacteria, fungi, archaea, protozoans, ciliates, earthworms, etc.). It should be noted that while compost promotes nutrient cycling and benefits crop growth, some organic and inorganic constituents introduced via compost could build up in soil imposing threats to the food chain through contamination and to the overall quality of the environment (Smith 2009, 2018). The application of compost to soil over a long period creates long-lasting positive and/or negative impressions on soil characteristics. Therefore, the safety concerns related to compost should be viewed holistically from handling of raw materials to production of compost to the consequences of end applications of the product.

Some contaminants in raw materials such as microbial pathogens and parasites could spread in the environment via animals such as flies and dogs in composting sites. Bio-aerosols and volatile compounds could enable transmission from composting sites to other environments with wind. In addition, leachates coming out from compost piles during the production process and runoff water from composting sites could contaminate surface water and groundwater and may cause serious health effects on people working on-site and off-site (Samarasinha et al. 2015).

In Sri Lanka, regulations for ensuring quality of compost with respect to inorganic constituents are in place and also being implemented. The chemical and physical parameters as mentioned in Table 4.1 are being monitored in the compost sold on the market. However, there are restrictions related to the capacity of regulatory bodies to satisfactorily survey the market to ensure product quality. However, policymakers and the general public are aware of the importance of the identified parameters in Table 4.1 for safeguarding human health and environmental quality. The following sections provide a brief overview of the emerging pollutants in compost, of which there is very limited awareness in Sri Lanka.

\subsection{Pollutants of Emerging Concern}

Most of the existing quality standards already address the maximum permissible levels of potentially toxic trace elements. However, very little attention is given to the organic pollutants in compost. The wide variety of substances, continuous changes in their structures and chemical natures due to biodegradation, lack of understanding on intermediary metabolites, and technological issues in identifying these compounds and their intermediary metabolites make organic pollutants a complex field to address when developing quality standards. Organic pollutants are commonly found in MSW-based compost. Bio-aerosols and volatile compounds are generally organic. In addition, micro- and nanoplastics as well as antimicrobial resistance determinants can be considered as emerging pollutants that could be introduced to the environment through compost and get transmitted into the food chain imposing threats on human and animal health. 


\section{Organic Pollutants and Bio-aerosols}

There is very limited information available on organic pollutants and bio-aerosols in compost despite the fact that scientific bodies have expressed their concern over the lack of monitoring of these compounds in compost as well as in composting facilities (Samarasinha et al. 2015). The leachate coming from MSW composting and dumping sites in Sri Lanka has been studied by a few groups (Gunawardana et al. 2009; Basnayake and Visvanathan 2014; Samarasinha et al. 2015). Gunawardana et al. (2009) observed that composting of MSW has reduced the organic pollutant content in leachate by seven times when compared to the leachate coming from untreated MSW. However, they have not gone into detail as to identify the organic pollutants in the leachate or in the compost itself. Research activities are ongoing to study the composition of gaseous emissions during composting and identifying potential organic pollutants in compost and their mobility in the environment. The importance of studying the impact of bio-aerosols (both chemical- and organismbased) released to the environment during the composting process on the health of workers at composting facilities in Sri Lanka is highlighted by Samarasinha et al. (2015). There is mounting evidence in literature on safety concerns and health risks associated with organic pollutants and bio-aerosols in compost and during its production and effects on end consumers and workers in other parts of the world (Fischer et al. 1999; Pearson et al. 2015).

\section{Microplastics}

Most of the microplastic- and nanoplastic-related studies are restricted to aquatic ecosystems, and only a very few concentrate on terrestrial environments. Although the discovery of microplastics and nanoplastics is new, these substances have entered Earth's ecosystems as early as the 1900s with commercial production and use of plastics around the world. Microplastics and nanoplastics in compost originate from MSW containing exfoliates in cosmetics and/or partially degraded larger plastic debris, including polyester fibres from fabrics, polyethylene fragments from plastic bags, plastic cans, and parts of electronic appliances (Galloway 2015). Plastic waste is common in MSW in Sri Lanka (Fig. 4.2) and contributes to a significant volume in the rejected pile after composting (Fig. 4.3).

Smith (2018) detected microplastics in MSW-based compost. Based on the observations so far, microplastics and nanoplastics, once added to soil, could influence micro-fauna and affect the soil food web (Rillig 2012). Changes in the dynamics of microbial communities affect soil properties leading to a chain of reactions influencing the ecosystem functions. Smith (2018) observed that microplastics introduced via compost could accumulate in plant tissues. Since micro- and nanosized plastics can bioaccumulate, there is a risk for human and animal health. As this is an emerging area of study, direct clinical evidences are lacking. However, potential influences of microplastics and nanoplastics on immune response-related disorders and cancer incidents are being suggested (Galloway 2015; Wright and 
Kelly 2017). Due to difficulties in studying the material, microplastic- and nanoplastic-related research is not yet popular. However, a few research programmes are being conducted on this group of pollutants as summarised in Galloway (2015) and Wright and Kelly (2017). There is no reported literature on the presence of microplastics and nanoplastics in compost and their possible consequences in Sri Lanka. Therefore, this is an area of research that must be initiated urgently, especially considering the wide use of compost and rejected piles from MSW-handling authorities for land management.

\section{Antibiotic Resistance Determinants}

Antibiotics are the most successful and sometimes the only treatment against infectious diseases caused by bacteria and fungi. However, the spread of antibiotic resistance traits among pathogenic groups of microorganisms is challenging the healthcare systems worldwide including Sri Lanka (Martinez 2009; Pruden et al. 2013; Liyanapathirana and Thevanesam 2016). Antibiotic residues, antibioticresistant bacteria, and genetic information containing antibiotic resistance genes (free DNA) are considered as antibiotic resistance determinants (Martinez 2009). While antibiotic residues exert a selection pressure, the organisms having the trait and the free DNA containing resistance genes serve as the genetic pool that facilitate horizontal gene transfer (Riber et al. 2014), speeding up the evolution of antibiotic resistance traits in a microbial community. The antibiotic resistance determinants are abundant in human and animal faecal material (Pruden et al. 2013), which is sometimes used as raw material for compost making as discussed in the previous section. Animal manure could harbour pathogenic microorganisms such as Salmonella spp., Listeria monocytogenes, and Escherichia coli $\mathrm{O} 157: \mathrm{H} 7$ that could contaminate fresh produce from crop lands and cause foodborne illnesses (Johannessen et al. 2004; Maffei et al. 2013). These organisms with enteric origin could easily develop multiple drug resistance traits. Although composting is being viewed as a method to reduce antibiotics in animal manure, some recent literature indicates that the degradation of antibiotics during composting is not uniform across different classes of antibiotics (Dolliver et al. 2008). Considering the large proportion of animal manure used by the composting industry in Sri Lanka, it is important to be cautious about the spread of antibiotic resistance traits along the food chain as a result of handling and processing of animal manures and human faeces.

\subsection{The Way Forward}

At present, the Central Environmental Authority of Sri Lanka is the government body involved in conducting environmental impact assessments for all industries operating at commercial scale. They should play an active role in ensuring environmental quality and safety in relation to composting facilities. The Sri Lanka Institute 
of Standards and the Consumer Affairs Authority are involved with ensuring the quality and safety of products in the market. Therefore, they have a major role to play to ensure the quality of compost. The knowledge gap with respect to pollutants of emerging concern and quality control of compost based on targeted end applications needs to be addressed by these authorities (as the authorities having the mandate to safeguard consumers and the environment) in collaboration with the scientific community in the country.

Efforts taken in the past to popularise compost production and use have not reached the expected outcomes mainly due to the lack of involvement of key stakeholder groups in project development and the decision-making process. The relevant government and corporate sector groups need to be consulted when developing strategies to improve the quality of compost as they are very aware of the unique challenges at ground level. It is also important to emphasise the need for obtaining the support of the scientific community, who can address the gaps, to ensure safe composting in the country. There should be proper coordination between the stakeholder groups to safeguard the environment against the spread of pollutants due to composting and the use of compost in agriculture and landfills. Funding agencies such as the National Science Foundation (NSF), National Research Council (NRC), and Sri Lanka Council for Agricultural Research Policy (SLCARP) could foster cooperation through financial support for projects done in a multidisciplinary nature addressing the key challenges previously presented in this chapter related to safe composting in Sri Lanka.

\section{Conclusions}

Compost production in Sri Lanka is happening at different scales and with a wide variety of biodegradable waste as raw material. The risks and limitations associated with the composting process and the quality of the end product are highly influenced by the scale of operation and the nature of raw materials used. MSW is a raw material with good potential for use in compost production, but there are a number of challenges to be addressed to overcome the negative impact on the environment and public health. One major aspect affecting the quality of MSW compost is the inadequate sorting/segregation of MSW used for compost production. MSW and poultry manure/litter, which are some common raw materials used in medium- to large-scale composting facilities in Sri Lanka, contribute to the spread of some pollutants of emerging concerns. Antimicrobial resistance determinants, micro- and nanoplastics, and organic pollutants are major emerging pollutants that have not yet received the attention of policymakers and regulatory bodies in Sri Lanka. 


\section{References}

Agegnehu, G., Bass, A. M., Nelson, P. N., Muirhead, B., Wright, G., \& Bird, M. I. (2015). Biochar and biochar-compost as soil amendments: Effects on peanut yield, soil properties and greenhouse gas emissions in tropical North Queensland, Australia. Agriculture, Ecosystems \& Environment, 213, 72-85.

Apata, D. F. (2012). The emergence of antibiotics resistance and utilization of probiotics for poultry production. Science Journal of Microbiology, 2, 8-12.

Arachchi, K. H. M. (2016). Present status of solid waste management and challenges for change. Colombo: National solid waste management program in Sri Lanka. Central Environmental Authority.

Basnayake, B. F. A., \& Visvanathan, C. (2014). Solid waste management in Sri Lanka. In Municipal solid waste management in Asia and the Pacific Islands (pp. 299-316). Singapore: Springer.

Chen, Z., \& Jiang, X. (2014). Microbiological safety of chicken litter or chicken litter-based organic fertilizers: A review. Agriculture, 4(1), 1-29.

da Cruz, N. F., Ferreira, S., Cabral, M., Simões, P., \& Marques, R. C. (2014). Packaging waste recycling in Europe: Is the industry paying for it? Waste Management, 34(2), 298-308.

Dandeniya, W. S., Herath, E. M., Kasinthar, M., Lowe, W. A. M., \& Jinadasa, R. N. (2018). Prevalence of antibiotic resistant bacteria in poultry litter based manures and potential threats on food safety for carrot. In Global symposium on soil pollution. Rome: Food and Agriculture Organization.

Déportes, I., Benoit-Guyod, J. L., \& Zmirou, D. (1995). Hazard to man and the environment posed by the use of urban waste compost: A review. Science of the Total Environment, 172(2-3), $197-222$.

Diarrassouba, F., Diarra, M. S., Bach, S., Delaquis, P., Pritchard, J., Topp, E., \& Skura, B. J. (2007). Antibiotic resistance and virulence genes in commensal Escherichia coli and Salmonella isolates from commercial broiler chicken farms. Journal of Food Protection, 70, 1316-1327.

Dolliver, H., Gupta, S., \& Noll, S. (2008). Antibiotic degradation during manure composting. Journal of Environmental Quality, 37(3), 1245-1253.

Dorahy, C. G., Pirie, A. D., McMaster, I., Muirhead, L., Pengelly, P., Chan, K. Y., Jackson, M., \& Barchia, I. M. (2009). Environmental risk assessment of compost prepared from Salvinia, Egeria densa, and Alligator weed. Journal of Environmental Quality, 38(4), 1483-1492.

Fischer, G., Schwalbe, R., Möller, M., Ostrowski, R., \& Dott, W. (1999). Species-specific production of Microbial Volatile Organic Compounds (MVOC) by airborne fungi from a compost facility. Chemosphere, 39(5), 795-810.

Franchetti, M. J. (2017). University waste reduction and pollution prevention assistance programs: Collaborations with industry, government and academia. In Sustainability practice and education on university campuses and beyond (pp. 50-59). Sharjah: Bentham Science Publishers.

Franke-Whittle, I. H., \& Insam, H. (2013). Treatment alternatives of slaughterhouse wastes, and their effect on the inactivation of different pathogens: A review. Critical Reviews in Microbiology, 39(2), 139-151.

Furtula, V., Farrell, E. G., Diarrassouba, F., Rempel, H., \& Diarra, M. S. (2010). Veterinary pharmaceuticals and antibiotic resistance of Escherichia coli isolates in poultry litter from commercial farms and controlled feeding trials. Poultry Science, 89, 180-188.

Galloway, T. S. (2015). Micro- and nano-plastics and human health. In Marine anthropogenic litter (pp. 347-370). Berlin: Springer.

Garcia-Gil, J. C., Plaza, C., Soler-Rovira, P., \& Polo, A. (2000). Long-term effects of municipal solid waste compost application on soil enzyme activities and microbial biomass. Soil Biology and Biochemistry, 32(13), 1907-1913.

Gerber, P., Opio, C., \& Steinfeld, H. (2007). Poultry production and the environment-a review. Animal production and health division, food and agriculture organization of the United Nations. FAO Publishing web. 
Gunawardana, E. G., Basnayake, B. F., Shimada, S., \& Iwata, T. (2009). Influence of biological pre-treatment of municipal solid waste on landfill behaviour in Sri Lanka. Waste Management \& Research, 27(5), 456-462.

Hamer, G. (2003). Solid waste treatment and disposal: Effects on public health and environmental safety. Biotechnology Advances, 22(1-2), 71-79.

Herath, E. M. (2017). Investigating the effect of poultry manure application on antibiotic resistance of bacteria in intensively cultivated soils. M.Phil. Thesis. Postgraduate Institute of Agriculture, University of Peradeniya, Sri Lanka.

Herath, E. M., Dandeniya, W. S., Samarasinghe, A. G. S. I., Bandara, T. P. M. S. D., \& Jinadasa, R. N. (2015). A preliminary investigation on methods of reducing antibiotic resistant bacteria in broiler litter in selected farms in mid country Sri Lanka. Tropical Agricultural Research Journal, 26(2), 412-417.

Herath, E. M., Palansooriya, A. G. K. N., Dandeniya, W. S., \& Jinadasa, R. N. (2016). An assessment of antibiotic resistant bacteria in poultry litter and agricultural soils in Kandy District, Sri Lanka. Tropical Agricultural Research Journal, 27(4), 389-398.

Hurst, C., Longhurst, P., Pollard, S., Smith, R., Jefferson, B., \& Gronow, J. (2005). Assessment of municipal waste compost as a daily cover material for odour control at landfill sites. Environmental Pollution, 135(1), 171-177.

IWMI. (2018). Human waste reuse could benefit farmers and improve public health in South Asia. International Water Management Institute, Sri Lanka.

Johannessen, G. S., Froseth, R. B., Solemdal, L., Jarp, J., Wasteson, Y., \& Rorvik, L. M. (2004). Influence of bovine manure as fertilizer on the bacteriological quality of organic iceberg lettuce. Journal of Applied Microbiology, 96(4), 787-794.

Kendaragama, K. M. A. (2006). Fertilizer use efficiency in farming systems in Sri Lanka. Journal of Soil Science Society of Sri Lanka, 8, 1-18.

Kendaragama, K. M. A., Lathiff, M. A., \& Chandrapala, A. G. (2001). Impact of vegetable cultivation on fertility status of soils in the Nuwara Eliya area. Annals of the Sri Lanka Department of Agriculture, 3, 95-100.

Kim, J., Luo, F., \& Jiang, X. (2009). Factors impacting the regrowth of Escherichia coli O157:H7 in dairy manure compost. Journal of Food Protection, 72(7), 1576-1584.

Liyanapathirana, V. C., \& Thevanesam, V. (2016). Combating antimicrobial resistance. Sri Lankan Journal of Infectious Diseases, 6(2), 72-82.

Maffei, D. F., Silveira, F. A. N., \& Mortatti Catanozi, M. P. L. (2013). Microbiological quality of organic and conventional vegetables sold in Brazil. Food Control, 29(1), 226-230.

Mapa, R. B. (2003). Sustainable soil management in the 21st century. Tropical Agricultural Research and Extension, 6, 44-48.

Martinez, J. L. (2009). Environmental pollution by antibiotics and by antibiotic resistance determinants. Environmental Pollution, 157(11), 2893-2902.

Nagarajah, S. (1986). Fertilizer recommendations for rice in Sri Lanka: A historical review. Journal of Soil Science Society of Sri Lanka, 4, 4-14.

Palm, O., \& Sandell, K. (1989). Sustainable agriculture and nitrogen supply in Sri Lanka: farmers' and scientists' perspective. Ambio, 18(8), 442-448.

Pearson, C., Littlewood, E., Douglas, P., Robertson, S., Gant, T. W., \& Hansell, A. L. (2015). Exposures and health outcomes in relation to bioaerosol emissions from composting facilities: A systematic review of occupational and community studies. Journal of Toxicology and Environmental Health Part B, 18(1), 43-69.

Premachandra, H. S. (2006). Household waste composting \& MSW recycling in Sri Lanka. In Asia $3 R$ conference, Tokyo.

Pruden, A., Larsson, D. J., Amézquita, A., Collignon, P., Brandt, K. K., Graham, D. W., Lazorchak, J. M., Suzuki, S., Silley, P., Snape, J. R., \& Topp, E. (2013). Management options for reducing the release of antibiotics and antibiotic resistance genes to the environment. Environmental Health Perspectives, 121(8), 878-885. 
Ram, L. C., \& Masto, R. E. (2014). Fly ash for soil amelioration: A review on the influence of ash blending with inorganic and organic amendments. Earth-Science Reviews, 128, 52-74.

Randall, L. P., Ridley, A. M., Cooles, S. W., Sharma, M., Sayers, A. R., Pumbwe, L., \& Woodward, M. J. (2003). Prevalence of multiple antibiotic resistance in 443 Campylobacter spp. Isolated from humans and animals. Journal of Antimicrobial Chemotherapy, 52(3), 507-510.

Riber, L., Poulsen, P. H., Al-Soud, W. A., Skov Hansen, L. B., Bergmark, L., Brejnrod, A., Norman, A., Hansen, L. H., Magid, J., \& Sørensen, S. J. (2014). Exploring the immediate and long-term impact on bacterial communities in soil amended with animal and urban organic waste fertilizers using pyrosequencing and screening for horizontal transfer of antibiotic resistance. FEMS Microbiology Ecology, 90(1), 206-224.

Rillig, M. C. (2012). Microplastic in terrestrial ecosystems and the soil? Environmental Science \& Technology, 46(12), 6453-6454.

Ryckeboer, J., Mergaert, J., Coosemans, J., Deprins, K., \& Swings, J. (2003). Microbiological aspects of biowaste during composting in monitored compost bin. Journal of Applied Microbiology, 94(1), 127-137.

Samarappuli, L. (2001). Nutrition. Handbook of rubber, volume 1: Agronomy (pp. 156-175). Rubber Research Institute of Sri Lanka, Sri Lanka.

Samarasinha, G. G. D. L. W., Bandara, M. A. C. S., \& Karunarathna, A. K. (2015). Municipal solid waste composting: Potentials and constraints (HARTI research report No: 174). Colombo: Hector Kobbekaduwa Agrarian Research and Training Institute.

Sanchez, P. A. (1997). Changing tropical soil fertility paradigms: From Brazil to Africa and back. In Plant-soil interactions at low pH (pp. 19-28). Piracicaba: Brazilian Society of Soil Science.

Sharma, R., Larney, F. J., Chen, J., Yanke, L. J., Morrison, M., Topp, E., Tim, A., McAllister, A., $\&$ Yu, Z. (2009). Selected antimicrobial resistance during composting of manure from cattle administered sub-therapeutic antimicrobial. Journal of Environmental Quality, 38, 567-575.

Sinnathamby, V., Paul, J. G., Dasanayaka, S. W. S. B., Gunawardena, S. H. P., \& Fernando, S. (2016). Factors affecting sustainability of municipal solid waste composting projects in Sri Lanka. 1st International Conference in Technology Management (iNCOTeM) (p. 98).

Smith, S. R. (2009). A critical review of the bioavailability and impacts of heavy metals in municipal solid waste composts compared to sewage sludge. Environment International, 35(1), $142-156$.

Smith, M. (2018). Do microplastic residuals in municipal compost bioaccumulate in plant tissue? M.Sc. Thesis. Faculty of Social and Applied Sciences, Royal Roads University, British Columbia, Canada.

Sri Lanka Standards Institution (SLSI). (2003). Specifications for municipal solid waste and agricultural waste. Technical Guidelines on Solid Waste Management in Sri Lanka, SLSI 1246:2003 (pp. 39-51). Central Environmental Authority, Sri Lanka.

Tennakoon, N. A., \& Bandara, S. H. (2003). Nutrient content of some locally available organic materials and their potential as alternative sources of nutrients for coconut. Cocos, 15, 23-30.

TRI advisory circular. (2000). Fertilizer recommendations for mature tea. Circular No. SP3. Serial No. 00/3. Tea Research Institute. Sri Lanka.

TRI advisory circular. (2016). Fertilizer recommendations for mature tea in small holdings. Interim circular No. SP10. Serial No. 01/16. Tea Research Institute, Sri Lanka.

Vision 2025 - A country Enriched. (2017). The changing face of a dynamic modern economy. Prime Minister's Office, Sri Lanka.

Walls, M. (2005). How local governments structure contracts with private firms: Economic theory and evidence on solid waste and recycling contracts. Public Works Management and Policy, 9, 206-222.

Weerahewa, J., Kodithuwakku, S. S., \& Ariyawardana, A. (2010). The fertilizer subsidy program in Sri Lanka. In Food policy for developing countries: Case studies. Ithaca/New York: Cornell University. 
Weerasinghe, P. (2017). Best practices of integrated plant nutrition system in Sri Lanka. Best practices of integrated plant nutrition system in SAARC Countries (pp. 135-160). Dhaka SAARC Agriculture Centre.

Wijetunga, C. S., \& Saito, K. (2017). Evaluating the fertilizer subsidy reforms in the rice production sector in Sri Lanka: A simulation analysis. Advances in Management and Applied Economics, 7(1), 31-51.

Wijewardena, J. D. H. (2005). Improvement of plant nutrient management for better farmer livelihood, food security and environment in Sri Lanka. In Improving plant nutrient management for better farmer livelihoods. In Proceedings of the workshop on food security and environmental sustainability (pp. 73-93). Beijing: FAO Publishing Web.

Wilkinson, K. G., Tee, E., Tomkins, R. B., Hepworth, G., \& Premier, R. (2011). Effect of heating and aging of poultry litter on the persistence of enteric bacteria. Poultry Science, 90(1), 10-18.

Wright, S. L., \& Kelly, F. J. (2017). Plastic and human health: A micro issue? Environmental Science \& Technology, 51(12), 6634-6647.

The opinions expressed in this chapter are those of the author(s) and do not necessarily reflect the views of the United Nations University Institute for Integrated Management of Material Fluxes and of Resources (UNU-FLORES), its Board of Directors, or the countries they represent.

Open Access This chapter is licensed under the terms of the Creative Commons Attribution 3.0 IGO license (https://creativecommons.org/licenses/by/3.0/igo/), which permits use, sharing, adaptation, distribution and reproduction in any medium or format, as long as you give appropriate credit to the United Nations University Institute for Integrated Management of Material Fluxes and of Resources (UNU-FLORES), provide a link to the Creative Commons license and indicate if changes were made.

Any dispute related to the use of the works of the United Nations University Institute for Integrated Management of Material Fluxes and of Resources (UNU-FLORES) that cannot be settled amicably shall be submitted to arbitration pursuant to the UNCITRAL rules. The use of the United Nations University Institute for Integrated Management of Material Fluxes and of Resources (UNU-FLORES)'s name for any purpose other than for attribution, and the use of the United Nations University Institute for Integrated Management of Material Fluxes and of Resources (UNU-FLORES)'s logo, shall be subject to a separate written license agreement between the United Nations University Institute for Integrated Management of Material Fluxes and of Resources (UNU-FLORES) and the user and is not authorized as part of this CC-IGO license. Note that the link provided above includes additional terms and conditions of the license.

The images or other third party material in this chapter are included in the chapter's Creative Commons license, unless indicated otherwise in a credit line to the material. If material is not included in the chapter's Creative Commons license and your intended use is not permitted by statutory regulation or exceeds the permitted use, you will need to obtain permission directly from the copyright holder.

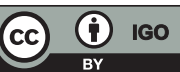

